International Journal of Engineering \& Technology, $7(3.29)(2018) 91-94$
SPC
International Journal of Engineering \& Technology
Website: $w w w . s c i e n c e p u b c o . c o m / i n d e x . p h p / I J E T$
Research paper

\title{
Redevelopment of buildings in Mumbai city: risks and challenges
}

\author{
Vinod Vanvari ${ }^{1}$ *, Dr. Sumedh Mhaske $^{2}$ \\ ${ }^{1}$ Research Scholar, 2Associate Professor and Former, Head of Department \\ ${ }^{2}$ Department of Civil and Environmental Engineering, Veermata Jijabai Technological Institute (VJTI), Matunga, Mumbai \\ *Corresponding author E-mail: vbvanvari@ rediffmail.com
}

\begin{abstract}
In most cities of developing countries, old buildings always tend to undergo redevelopment. There are one or more than one reasons for this. Such as buildings which are in dilapidated condition or uneconomic to repair or tenants are in a need of more usable floor area. This activity of building redevelopment is much visible in Mumbai city for past decade and half. Because of various constraints and considerations, this process of projects of building redevelopment is quite complex. It takes considerable efforts and time to accomplish the projects. If a proper and time bound process is not followed, or if the risks, uncertainties and challenges are not handled properly, even a seemingly simple project can fail, thereby causing great anguish and hardship to the stakeholders. Sometimes this may lead to prolonged litigation. There is a need to identify risks and challenges involved in the process of building redevelopment projects. The aim of researchers is to interact with all the stakeholders of building development projects of housing societies and identify various risks and challenges visa-a-vis gains. The study has also revealed various pitfalls and uncertainties related to these projects. This will enable concerned stakeholders to prepare to address these.
\end{abstract}

Keywords: Challenges; Housing Societies; Redevelopment; Risks.

\section{Introduction}

It is certain that urban areas transform themselves over time. Old buildings required to be redeveloped once they surpass their useful life. Nelson A (2014) [1] has while giving illustration about working out optimal time of redevelopment, explains that over a period, there is appreciation in land and depreciation in the structure of building. It is much more appropriate to redevelop building once value of land surpasses value of building. The situation in most of the buildings in Mumbai city is similar to this theory. Old buildings having a life of 20 to 40 years, while value of land with prevailing development control rules is much more than present value of their building and their usefulness. In Mumbai city, many buildings are subjected to the process of redevelopment irrespective of their age or life span. For this, reasons are many such as fear of collapse due to dilapidated condition of buildings, uneconomic to repair or need of more area or amenities or funds or combination of more than one of reasons. Due to quite a few gains supplemented by unavoidable circumstances, members go for redevelopment of their buildings in spite of risks and challenges involved.

Building redevelopment activity is quite complex due to various factors, dimensions and multiple stake holders. It is a multifaceted activity. It is imperative to understand risks and challenges beforehand.

\section{Study area and relevance}

This research study is focused on finding the risks and challenges of the process of building redevelopment projects in Mumbai city. This city is commercial capital of India, located at latitude $19.0760^{\circ}$
$\mathrm{N}$, departure $72.8777^{\circ} \mathrm{E}$. The total area of three administrative parts (city proper, western and eastern suburbs) is 45628.49 Hectares. Questionnaire survey carried out to capture global scenario with respect to redevelopment activity for few cities across the globe, reveals that redevelopment of buildings activity is not only very active in Mumbai city (90\% proposals in building proposal department are of redevelopment), but also has unique pattern for process of delivery. This reflects relevance of study.

The building redevelopment projects in Mumbai city are classified into the following types.

a) Slum Rehabilitation Projects and Cluster Redevelopment: Handled by State Government owned bodies.

b) Buildings due for redevelopment on collector's land: These are dependent on government policies.

c) Individual Housing Societies: Weak and dilapidated buildings more than 30 years old. Tenants of these co-op societies need to take initiative themselves to move for redevelopment at their risk, cost and time.

This research work is carried out for the third type of projects i.e. building redevelopment projects of individual housing societies.

\section{Methods}

The present study is carried out in the four stages:-

1) Pilot Questionnaire survey.

2) Study of risks, pitfalls, challenges and uncertainties

3) Interaction with all the stake holders.

4) Assimilation and analysis.

\subsection{Pilot questionnaire survey}


The small sample of tenants was identified from housing societies under redevelopment. Simple questionnaire was designed to undertake this. The factors identified were incorporated in pilot questionnaire survey.

The attributes identified were presented to respondents. The respondents (tenants, ten in number) were requested to respond to this. The rating of one most important attribute i.e. "Level of Risk" were sought on 1 to 10 scales, "1" represented "Strong disagreement" and "10" represented "Strong agreement ". (See Table I).

The outcome of analysis of Pilot Questionnaire can be summarized as follows:

1) The learned and updated lot among tenants feels relatively less risk in the process. [2].

2) Risk varies from project to project, person to person, phase to phase.

Table 1: Level of Risk

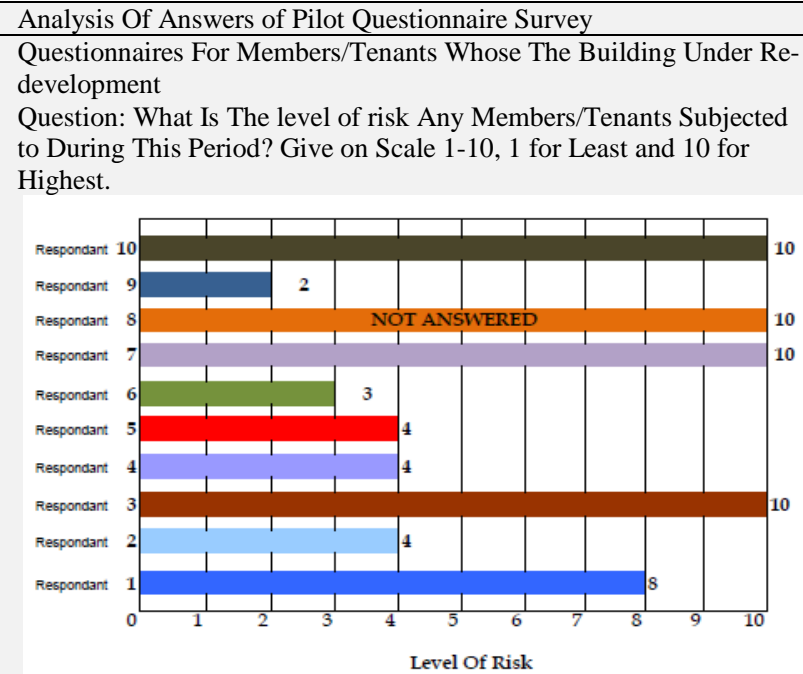

Mean Deviation=3.01 Standard Deviation $=3.14$ Variance $=51.41 \%$

(Source: Conceptualized by author)

See Table II for project phases and risks

Table 2: Project Phases and Risks

\begin{tabular}{|c|c|c|}
\hline Phase of Project & $\begin{array}{l}\text { Risk } \\
\text { Level }\end{array}$ & $\begin{array}{l}\text { Duration in } \\
\text { Months }\end{array}$ \\
\hline $\begin{array}{l}1 \text { Initial Preparation and PMC Se- } \\
\text { lection }\end{array}$ & $\begin{array}{l}\text { Very } \\
\text { High }\end{array}$ & 2 to 3 \\
\hline 2 Project Feasibility & $\begin{array}{l}\text { Very } \\
\text { High }\end{array}$ & 2 to 4 \\
\hline $\begin{array}{l}3 \text { Tendering, Developer Selection } \\
4 \text { Pre-execution } \\
5 \text { Construction, Handing over }\end{array}$ & $\begin{array}{l}\text { High } \\
\text { Medium } \\
\text { Moderate } \\
\text { Total }\end{array}$ & $\begin{array}{l}6 \text { to } 8 \\
8 \text { to } 10 \\
27 \text { to } 59 \\
45 \text { to } 59 \\
4 \text { to } 5 \text { Years }\end{array}$ \\
\hline
\end{tabular}

(Source: [3]).

\subsection{Study of risks pitfalls uncertainties and challenges}

Risk is an abstract term. In a given situation, risk is viewed differently by different people. Risk in general signifies an uncertain event, situation, or condition which may occur. It may have either a positive or negative effect on the project objectives. Some risks may pose a threat to the achievement of objectives, whereas unfavorable risks are termed as threats.

Building redevelopment project is one type of turnkey reconstruction contract. Risk checklist of such project is given below. This list is indicative but not limited to the following: [4].

1) Project scope.

2) Design and Specifications risks.

3) Quality Risks.

4) Time overrun risks.

5) Cost overrun risks.

6) Leadership risks.

7) Organizational risks.
8) Physical resources, mobilization and utilization risks.

9) Technology risk.

10) Contractual risk.

11) Force Majeure and ecological risks.

12) Political, WTO, Legal and social risks.

Pitfalls are nothing but hidden risks. Building redevelopment projects are multifarious projects with multi-stake holders. There can be many pitfalls.

Uncertainties are happenings which are unpredictable. Redevelopment projects may prolong over four to five years or more. During this gestation period, projects are prone to various kinds of uncertainties.

Challenges are peculiar problems encountered during the process of projects. The solution to these challenges needs to be arrived at.

\subsection{Interaction with the stakeholders}

After having studied risks, pitfalls, challenges and uncertainties, interaction was carried out with all the stake holders of all the projects at different stages of redevelopment (all the four: those on anvil, under progress and complete and also including ones those are on hold) of housing societies. These stake holders include tenants, builders/developers, experts (Architects, Project Management Consultants, and Advocates) and officials from regulatory authorities such as MCGM, MHADA etc. This interaction was undertaken through interviews (with prior appointments) and structured questionnaires. Total 34 interviews of stakeholders were conducted comprising developers, experts and secretaries representing housing societies. The pre-designed questionnaires were put to these stake holders. The inputs received are very vital, important and are of high relevance. From these risks and challenges to the projects were identified.

\subsection{Assimilation and analysis}

The questionnaires were put to 215 stake holders (Tenants, Developers and Experts) of housing societies projects under various stages of redevelopment. Total 116 valid responses were received. The assimilation of inputs from interview and analysis of data from questionnaire was carried out. The same is classified into the following compartments.

- Preliminary findings.

- Pitfalls in process

- Risks and challenges.

\subsubsection{Preliminary findings}

The Mumbai city has unique geography and geometry. It is more long than wide. It is surrounded by sea on three sides. City is commercial capital of India. Land is very scarce commodity here. Demand for housing always persists. This leads to high housing price index. Tenants and developers are two active partners and stake holders in venturing into process of building redevelopment of housing societies. Tenants opt for this option as it leads to the following gains.

1) New flat with additional area. Expanding growing family needs are met in same location.

2) New building with earthquake resistant, modern design, good look, lift facility and other amenities like parking garden swimming pool and club house etc.

3) Monetary benefits in terms of corpus fund to cover up future increases in taxes and maintenance charges.

4) Wealth creation. The housing unit when fully redeveloped has potential value of 2.5 times the present value of old unit. The developers by virtue of additional FSI available as per prevailing norms constructs additional housing units termed as sale flats which not only generate funds for reconstruction but also decent mark up for them.

In view of above gains, both tenants and developers are tempted to go for redevelopment and many times ignoring risks and challenges 
involved. This paper attempts to identify, risks, pitfalls and challenges.

\subsubsection{Pitfalls, risks and challenges}

Further assimilation of inputs gathered from interviews and analysis of response received from pre-designed questionnaire, the outcome was consolidated into pitfalls, risks, challenges and uncertainties involved in the process of building redevelopment projects of housing societies in Mumbai city. The discussion follows subsequently.

\section{Outcome}

Outcome of this research work is as below

1) Probable pitfalls.

2) Risks and Challenges.

3) Uncertainties.

\subsection{Probable pitfalls}

Building redevelopment projects in Mumbai City is highly risk taking venture for both the parties' i.e. the Tenants/members of housing society and also for the developer.

Following are the probable pitfalls for which the members/tenants need to be careful.

- Organization and resourcefulness of the developer. If there is more than one partners/director, then in future there always remains possibility of split of business among them due to separation. Projects get divided among into future sub companies. Project allocated to less resourceful partner's company is prone to risk of delay and even non completion. This risk can be mitigated to sufficient extent by proper water tight development agreement at initial stage.

- Boundaries and area of plot on which old building stands, neither match w.r.t. city survey maps nor town planning maps. Remarks by respective authorities may not be clear or even pending. It takes quite some time and huge efforts to sort out such types of mess. Hence to avoid falling into this pit fall, it is imperative to get total survey carried out during feasibility stage of the project.

Following are the probable pitfalls for which developer need to be careful before venturing ahead in building redevelopment projects of housing societies.

- Development Control regulations and likely changes expected in near future.

- Conflicting attitudes among members/tenants of housing societies.

- Records and remarks pertaining to the land and building on the piece of land whose redevelopment is to be undertaken.

Following are the major pitfalls as summarized below.

- Unclear/ Title, Restrictive policies, stays
- Wrong/Misguided Perceptions about project

- Personal, Vested interests, Resistance, opposition

- Weak, Indecisive Managing Committee, Absence of Leadership

- Non cooperative/Egoistic/Misguided redevelopment committee

- Not following 79A as basic process

- No Time plan, No Timely Decisions

- Inexperienced /Incompetent PMC, Legal Advisor

- Less/Excessive Transparency, Communication

- Not addressing internal conflict/Misconception

- Inadequate property documents/No variation

- No consensus on member information eg. Carpet area

- Unreasonable commercial expectations. Greed among some members.

- Waiting for favorable policies.

- No strategy, No focus, wrong priorities.

- Inferior tender document and bidding process.

- Inadequate /false disclosure to bidders.

- Incorrect criteria for selecting developer.

- No due diligence while selecting a developer

- Inability to get consent of $75 \%$ members for redevelopment.

- Inferior legal document.

- No provision for Dispute Resolution process

- No provision for changing policies like sharing of additional FSI, in future

- Ignoring Security Measures

- Delay in Signing Development Agreement

- Non Vacating Members

- Vacating without due Diligence

- Unsupervised Construction

- No Progress Review

- Poor Project Documentation

- Absence of a Fair and Practical View [3]

\subsection{Risks and challenges}

Process of building redevelopment is complex and challenging. This is further complex in case of projects of housing societies. There are multi-stakeholders with varied knowledge, wisdom, expertise and socio-economic status. Dilapidated condition of buildings, Changing development control rules by regulatory authorities, market conditions contribute major risks, while physical condition of plot, coherency among tenants, making them vacant to alternate accommodation, mobilizing finance are major challenges.

If proper detailed feasibility study carried out at beginning, risks and challenges can be foreseen. Through proper discussion, transparency and communication same can be addressed during initiation phase itself. (See Table III and IV).

Table 3: Risks to Various Parties in Building Redevelopment

\begin{tabular}{|c|c|c|c|}
\hline A & Risks to both parties & Key Factor & Remark \\
\hline 1 & $\begin{array}{l}\text { Allowable FSI changes due to changing DC rules } \\
\text { and policies }\end{array}$ & $\begin{array}{l}\text { Clause to allocate distribution of FSI in case } \\
\text { of increase. Proportion is predicted without } \\
\text { calculations. }\end{array}$ & $\begin{array}{l}\text { Some societies have started to adopt } \\
\text { this. }\end{array}$ \\
\hline 2 & $\begin{array}{l}\text { Housing units i.e. flats do not churn out to the ex- } \\
\text { act committed area as per DA after planning and } \\
\text { also complying DC rules }\end{array}$ & $\begin{array}{l}\text { Clause to compensate for } \pm \text { area as per pre- } \\
\text { defined rate. }\end{array}$ & Being adopted \\
\hline B & Risks to Tenants & Key Factor & Remark \\
\hline 1 & Developer does not initiate proposal after selection & Security deposit & $\begin{array}{l}\text { Security Deposit of } 1.5 \mathrm{cr} \text { for project } \\
\text { of } 20 \text { tenants }\end{array}$ \\
\hline 2 & Developer does not enter DA, lingers & Time limit of 03 months after selection & \\
\hline 3 & Abandons construction mid-way & Bank Guarantee $=1.5$ construction cost & \\
\hline 4 & Ensure specific quality measure & Annex tender with DA & $\begin{array}{l}\text { One big society in suburbs of Mum- } \\
\text { bai got adopted corrosion resistance } \\
\text { steel }\end{array}$ \\
\hline 5 & Builder Stops giving rent & & \\
\hline 6 & Changes in rent & Suitable clause addresses this & $\begin{array}{l}\text { Predicted increase after every } 12 \\
\text { months }\end{array}$ \\
\hline
\end{tabular}




\begin{tabular}{llll}
\hline C & Risks to Developer & Key Factor & Remark \\
1 & Delay by tenant/s in vacating flats in old building & DA with strict penalty clause & May not be possible \\
2 & Increase in Ready Reckoned rates & Approval in one go & Approval in one go \\
3 & Increase in Premiums & Clause with basic price can be incorporated & Not adopted as of now \\
4 & Changing TDR prices & Clause can be evolved linking corpus, rent & Not adopted as of now \\
5 & Loading of TDR in one go/parts & \& area. & \\
\hline
\end{tabular}

(Source: Conceptualized by author)

Table 4: Challenges to Various Parties in Building Redevelopment

\begin{tabular}{|c|c|c|c|}
\hline A & Challenges to both parties & Key Factor & Remark \\
\hline 1 & $\begin{array}{l}\text { Dilapidated condition of building or building in irreparable } \\
\text { condition. }\end{array}$ & $\begin{array}{l}\text { Structural audit and acting on its recom- } \\
\text { mendation of its report. }\end{array}$ & $\begin{array}{l}\text { MCGM guidelines to be followed for } \\
\text { classification of buildings. }\end{array}$ \\
\hline 2 & Sustaining coherency among tenants & $\begin{array}{l}\text { Ensuring transparency and communica- } \\
\text { tion. }\end{array}$ & \\
\hline B & Challenges to Tenants & Key Factor & Remark \\
\hline 1 & $\begin{array}{l}\text { Project becomes non feasible due to one or other reason } \\
\text { after selecting and appointing developer. }\end{array}$ & $\begin{array}{l}\text { Getting detailed feasibility before or re- } \\
\text { visiting development agreement if such } \\
\text { situation arises. }\end{array}$ & Feasibility need to be dynamic. \\
\hline 2 & Developer less resourceful with respect to finance. & $\begin{array}{l}\text { Due diligence or bringing other devel- } \\
\text { oper with proper settlement of previous } \\
\text { developer. }\end{array}$ & \\
\hline $\mathrm{C}$ & Challenges to Developer & Key Factor & Remark \\
\hline 1 & $\begin{array}{l}\text { Sudden shortage or unavailability of any construction ma- } \\
\text { terial. }\end{array}$ & $\begin{array}{l}\text { Adopt alternate material with consulta- } \\
\text { tion of Expert. }\end{array}$ & \\
\hline 2 & $\begin{array}{l}\text { Challenging local site conditions like low water table or } \\
\text { surrounding buildings requiring silence like hospitals or } \\
\text { educational institutes. }\end{array}$ & $\begin{array}{l}\text { Pre-bid survey necessary or resolving } \\
\text { such challenges with mutual discussions } \\
\text { and meetings. }\end{array}$ & \\
\hline $\mathrm{D}$ & $\begin{array}{l}\text { Special challenges } \\
\text { No conveyance, Earlier failure, Height restriction, High- } \\
\text { way /Railway, MOEF, CRZ, Group Redevelopment and } \\
\text { Self Redevelopment. }\end{array}$ & & $\begin{array}{l}\text { These are specific challenges they } \\
\text { may be there or not, varies from pro- } \\
\text { ject to project. }\end{array}$ \\
\hline
\end{tabular}

Notes: Terms Used:

$\mathrm{CRZ}=$ Coastal Regulation Zone

DA $=$ Development Agreement

$\mathrm{DP}=$ Development Plan

DCR $=$ Development Control Regulations

FSI $=$ Floor Space Index

MCGM = Municipal Corporation of Greater Mumbai

MHADA = Maharashtra Housing Area Development Authority.

MOEF $=$ Ministry of Environment and Forest

\subsection{Uncertainties}

Building redevelopment projects are hot-bed for various uncertainties and every possible dispute. Few are listed below.

- Market conditions: Though location of building redevelopment projects govern price of sale flats, however general mood in real estate market does have impact on project.

- Delay in implementation of DP and DCR.

- Defective Title of plot

- Non Co-operative members

- Non performing Developer

- Changing Regulations and Policies.

- Other policies: Inclusive housing, Buffers, NOCs, Civil aviation, Approvals costs, Court orders, stays etc.

\section{References}

[1] Nelson A; "The cycle of Development, optimal Redevelopment, Redevelopment Goals and Benefits an nd Barriers to Redevelopment," Fundamentals of Real Estate Financing, Springer Link, 2014, pp 937.
[2] Vanvari V, Mhaske S; "Systems Approach for Project Process of Redevelopment of Buildings in City of Mumbai" seventh NCESS, Aakar, IIT Bombay, 2015.

[3] Darglakar U; "Pitfalls and Failures in Redevelopment", seminar, Mumbai 2018.

[4] Chitkara K.K; "Construction Project Management", Tata MC Graw Hill Publishing Company, New Delhi, 1999. 